\title{
An ESP Teaching Proposal for Oil and Gas Vocational Courses
}

\author{
Wigna Thalissa Guerra \\ BR 405, KM 154, Bairro Chico Cajá \\ IFRN - Campus Pau dos Ferros \\ Samuel de Carvalho Lima \\ Rua Raimundo Firmino de Oliveira, 400 - Conj \\ Ulrick Graff -Mossoró/RN CEP: 59.628-330 \\ IFRN -Campus Mossoró
}

\begin{abstract}
The purpose of this study was to elucidate the way English for Specific Purposes (ESP) has been taught at a federal public school responsible for the offer of vocational courses in Rio Grande do Norte, Brazil. We analyzed ESP syllabus in Oil and Gas vocational course, considering ESP basic principles and the pedagogy of multiliteracies. Questionnaires were applied with students as well as semi-structured interviews with 2 teachers of the course. The sections of theESP teaching proposal were elaborated considering ESP needs analysis, contents, resources and general proceduresthat were guided by the blanks we noticed in the syllabus concerning the underlying principles of ESP and the pedagogy of multiliteracies, students' opinions as well as what teachers highlighted as a good ESP course.Data analysis led us to design an ESP teaching proposal for vocational courses focusing on reading (newspaper news) and oral communication (business meetings) to be used by and initially guide English teachers' practices in Professional and Technological Education settings.
\end{abstract}

Keywords: ESP; Teaching; Vocational Education.

\section{Introduction}

After the end of the Second World War, there was a great expansion of technology and international trade. According to Hutchinson and Waters (1987), the diffusion of English as a multilateral language became easier after this expansion. The great economic power of the USA ended up by establishing English as a multilateral language and the interest in learning it increased and became a necessity to the globalized world. The so-called English for Specific Purposes (ESP), known in Brazil as Instrumental English, starts its development at this time as an approach to learn the language.

ESP has been defined as a field of language teaching in which the necessity of the learner with regard to the foreign language is the starting point for developing a course design (HUTCHINSON; WATERS, 1987; DUDLEY-EVANS; ST. JOHN, 1998). Studies agree in some ESP basic characteristics: learners' necessities (professions, specific activities), appropriate language (lexicon, syntax, semantics, discourse analysis), no predetermined methodology. In Brazil, Celani (1998) argues that an ESP teacher is a foreign language knowledge mediator, since the subject content may be new to the teacher, while most students might have already had the opportunity to study some of the specific contents in previous, sometimes more professional, contexts. The exclusivity on text reading (RAMOS, 2008), the starting point of ESP in Brazil, is the result of what the Brazilian National ESP Project aimed atthe time of its beginning: help professors to becomeproficient in the foreign language, since great part of the literature available at universities was written in English. However, this emphasis may not be appropriate to every single ESP course nowadays. When considering vocational courses, it is important to think about how the future professionals might make use of the foreign language in their eventual professional settings.

Furthermore, when students face real life situations and get involved with their own contexts, they also becomeresponsiblefor the construction of their own knowledge. This way the process of teaching and learning should promote a transformation on students' lives (NEW LONDON GROUP, 1996; COPE; KALANTZIS, 2009). Therefore teaching should consider the external aspects of students' life, students' social contexts and background knowledge, turning the students into a real participant of the learning process. This leads to the following questions: are students' needs being considered in ESP for vocational courses? What could teachers do to improve ESP offer? 
In order to address the previous questions, the aim of this paper is to analyze how ESP has been taught at a federal public school located in Rio Grande do Norte, Brazil. The school is responsible for the offer of several vocational courses, and Oil and Gas vocational course is one of the courses in which ESP is a specific subject.Thus we tried to understand which theories and methodologies have been supporting the development of this subject in Professional and Technological Education resultingin the elaboration of an ESP teaching proposal for vocational courses in Brazil.

\section{Research Context and Methodological Choices}

Our study took place at a federal public school located in Rio Grande do Norte, Brazil. The Instituto Federal de Educação, Ciência e Tecnologia do Rio Grande do Norte (Federal Institute of Education, Science and Technology of Rio Grande do Norte) has had many other denominations and scopes. The current denomination took place in 2008 through a federal government law that created the Federal Institutes all over Brazil (BRASIL, 2008). Today, the Institution has 21 campistate-wide, covering a wide range of courses: 122 courses of professional qualification, 86 secondary vocational courses, 31 undergraduate courses and 19 postgraduate courses. We focused on Oil and Gas vocational course because it is the only course in which ESP plays a role in the course program in Mossoró, the city where this research was developed.ESP is compulsory for this course, with a workload of 30 hoursin the first semester of the vocational course.

We analyzedOil and Gas Pedagogical Project which is the document that gives directions on planning the courses' classes and that is closely connected to the Political-pedagogical Project of the institution. Basically, Oil and Gas Pedagogical Project presents the following sections: justification, objectives, requirements and access ways, professional profile, curriculum organization, learning evaluation criteria, credit/course transfer and knowledge certification, facilities and equipment, library, teaching and management staff and certificates and diplomas. One of the main aims of the course is to educate a professional who is not only a technician, but also a citizen, accomplishing an integrated education. The document also shows a strong commitment with ethic principles. Moreover, interdisciplinarity is one of the most recurring words of the document. It is clear that this might be on the center of teachers' work: they have to develop their classes considering what could be an interdisciplinary course. The document makes it clear that this is an important feature and that the institution should provide teachers with enough time to develop interdisciplinary projects.

In what regardsthe methodologies, the document prescribes that such processes have to be developed in a way that secondary and professional education can be conjugated. On this section, it is clear that students' interests, characteristics and previous knowledge should be considered. The participants of the research were students and teachers of the institution. The students werefrom the night shift, regularly enrolled at the course. The official amount of students was 41, but only 31 answered the questionnaire on needs and wants (HUTCHINSON; WATERS, 1987; ROBINSON, 1991; DUDLEY-EVANS; ST. JOHN, 1998). Classes lasted 1,5 hour a week. The majority of the students worked during the day andsome of them depended on public transportation to come to classes. The teachers that took part of the investigation were the ESP teacher and an engineer responsible for teaching the specific technical subjects, both public servants of the institution who agreed to be interviewed.Interviews and questionnaires are highly recommended instruments to carry out a needs analysis. It was extremely important to get to know what students and teachers have to say about the ESP teaching to guide us in the construction of our proposal. All participants of theinvestigationhavesigned the informed consent form and have their identities preserved.

\section{Findings and Discussion}

Despite the great quantity of courses being offered at the institution, only 10 present ESP as a subject, and the Oil and Gas is one of them. Our first consideration is that English in such courses should be taught considering the contexts the future technicians might be involved with. After analysing the Course Pedagogical Projects, we could notice three main focuses of ESP and the presence (or not) of multiliteracies features. Here, we present only the findings regarding the Oil and Gas Technical Course. This first analysis helped us to understand how ESP is being taught and made us realize that the teaching proposal is flexible enough to be used in any course with similar purposes, regardless ofdifferent specific areas. Our analysis took three sections of the course program: the syllabus main topic, objectives and contents. Data interpretation allows us to say that the Oil and Gas program is based on methodologies that deal exclusively with reading and writing, what can be explained as a heritage of the beginning of ESP in Brazil (RAMOS, 2008). This can be seen more evidently at the first topic of the syllabus: "reading, interpretation and production of technical-scientific texts" (IFRN, 2012: 36). The syllabus does not consider other possible necessities of the students, such as communication or oral genres. Thus, aspects of ESP or multiliteracies seem not to be considered such as the process of needs analysis or communication through what students consider meaningful genres to them. 
In the objectives section, once again the teaching of reading is highlighted and the importanceoforal genres is minimized. It is presupposed that the texts that teachers should bring to class are those with specific contents of the oil and gas industry and it is implied that they are only written texts with no reference to actual genres.In what refers to multiliteracies, it emphasizes that it is necessary to make students understand how important English is to their future profession, but it does not bring any indication of the work with different modalities or the concern with students' background, previous knowledge and experiences.The last section analysed was the one about the contents: reading strategies, translation techniques and grammar topics are the topics indicated. We could not notice any features of multiliteracies in this section. From this first analysis, it was possible to understand that the ESP program of Oil and Gas course has not been guided by ESP or multiliteracies principles. This fact makes us reflect on possible ways to complement the Course Pedagogical Project, especially ESP program, elaborating a teaching proposalin which reading specific vocabulary from a technical field is a constituent and not the core of the course syllabus.

Considered one important instrument of data collection during the needs analysis process, the questionnaire answered by the students helped us to develop the design of our teaching proposal. 27 students were in the classroom at the day of application. In order to learn technical vocabulary, news appeared as the favorite genre of the students with $63 \%$ of choice (17 students). The scientific article was chosen by 18\% (5 students); manual counted on 15\% (4 students) and $4 \%$ (only 1 student) chose the option "others", answering "English for oil and gas", but not specifying any genre. Since students showed a great interest in news, one of the features of our proposal considered this text genre, aswe understandthe importance ofstudents' needs and wants an important andnecessarycharacteristic to develop a teaching proposal (HUTCHINSON; WATERS, 1987; ROBINSON, 1991; DUDLEY-EVANS; ST. JOHN, 1998).

It is important to make clear that the genre chosen by the students is a significant way to reach our goals.Firstly, due to the need to meet what the program of the course presents, which isthe focus on reading. Secondly, because we intend to consider reading in a perspective that goes beyond reading strategies, helping students to reflect critically about what they read both in a local and a global sphere what is possible through the news. Through the questionnaire, we also noticed that students think that English is extremely important for the Oil and Gasprofessional field and that communication is one of students' main concerns. The four categories that emerged from students' answers when being asked about the importance of English for the field were: English for communication, English for professional development; English for reading; English for the international industry.

From the students answers we could start to take some decisions concerning our proposal: it is important to consider reading news, consider their future professional contexts, the understanding that the industry is international and, mainly, that speaking the language is the key point for their professional development, since communication for them means especially oral production. Someanswers mentioned that one of the possibilities of engagement in the language is the business meetings, since they could be part of decisions concerning the purchase of machines, for example. This led us to consider this oral speech genre as the core of the teaching proposal we present, leading studentsto be able to perform roles in a business meetingby the end of two months of classes. The semi-structured interview carried out with the ESP teacher was developed in order to understand his beliefs and opinions on ESP teaching to oil and gas students, as well as to understand which methodologies and materials are usually used in the ESP subject at the institution. From data analysis ofthe ESP teacher's interview, we could highlight some important concerns: the course load; the oil and gas industry in an international perspective; the machines used by oil and gas technicians; materials; reading and speaking.

According to the ESPteacher, the course load of 30h a semester is insufficient to develop an efficient work. He believes that "maybe $[\ldots]$ three semesters could help students to have a better course". The ESP teacher also thinks that the time is not enough to work with "meaningfulactivities". Based on his beliefs, we understood that it was necessary to develop ways to work with the short workload, what led us to consider homework to complement what was taught during the classes. The teacher also considers the international perspective of the oil and gas industry. It is said that this is "a field in which the import and export of workforce is very common". Considering thepossibility of workers coming and leaving the country for work,communication between workers from different nations becomesan issue to be carefullythought. The awareness of variations and the respect to particularities of different cultures become an important issue in a teaching proposal that respects multiliteracies perspective(COPE; KALANTZIS, 2009).

Data analysis also confirmed that the ESP taught at the schooltoday has still a great influence of the National Project, focusing almost exclusively on reading (CELANI et al, 1988; RAMOS, 2008). According to the teacher, "[...] reading and text interpretation is the focus of the course". The course program, the official document that guides the teacher's practice, has a focus on reading and the ESP teacher tries to follow what is presented in the syllabus.However, he tries to go further, bringing oral production that should be "minimally" developed (IFRN, 2012: 32). 
The ESP teacher believes that it is necessary to go beyond the minimum, since "[...] ESP should not be worked considering only reading, because in the workplace, there is more than written texts. You listen to requests, orientations, and if you understand what is being asked, it helps a lot".

The development of activities that deal with oral communication is necessary, since the future professional faces different situations that go beyond written texts. Communication is, according to the teacher interviewed, an absolutely relevantskill to oil and gas professionals, and by communication he means speaking.Other important aspect mentioned by the teacher is the necessity of reading skills, since the technicians deal with machines that present functions written in English, as well as their manuals. Students need, then, to acquire specific vocabulary and learn to read thoseinstructions. In what refers to the available materials to ESP teaching, the internet was pointed as the greatest source of materials: "There is a great quantity of materials on the internet. There are lots of things we can adapt and use in the classroom. That is exactly what I do. [...] Videos, texts, a variety of things". Materials are the result of adaptations from what is found on the internet and used according to the contents proposed on the syllabus. Texts that may be used by the companies that the students might work eventually are considered by the teacher. The use of videos is also a procedure adopted by the ESP teacher:"Videos that present some procedures [...]. So there is a quite specific vocabulary. They see the image, the video, they listen to the audio in English and see the subtitles also in English. It is really nice and helps a lot".

It is worth mentioning that even though the ESP program does not bring any explicit information on the matter, the ESP teacher makes use of a resource that can meet multiliteracies principles, once the teacher explores videos affordances. Such videos might help students to develop listening comprehension and conjugate images, words and audio, integrating different modalities (NEW LONDON GROUP, 1996). Taking into consideration what is proposed bythe Political Pedagogical Project and the Course Pedagogical Project of IFRN (2012) as well as ESP principles,we also emphasize the necessity of an interdisciplinary work.Thus, our second interview was carried out with an engineer responsible for teaching in the specific subjects of the vocational course. From data analysis of the engineer's interview, we could highlight some important concerns: the course load; the oil and gas industry in an international perspective; reading and speaking; interactions between the teachers; language teacher education.

According to the engineer, the main difficulties students have regarding English are oral communication and reading. The engineer highlights that professionals who are part of oil and gas industry are fluent in English. This is explained due to the international context the industry belongs, promoting the exchange of information with companies' representatives and manufacturers around the world, what demands the ability to speak in English, as well as reading in this language.

The course load and teacher education were mentioned by the engineer as difficulties to the learning process, since he says that "the course load we have is short, and it becomes difficult to work with what the syllabus proposes and the teachers themselves. [...] they should be trained to understand the processes and, then, teach". The engineermakes it explicit many times along the interview that he suggeststo increase the course load, but we understand that this is a long-term solution.

The engineer also explained to us that one of the most important points of the Pedagogical Political Project of IFRN is not being accomplished at the institution: the interdisciplinary work. He says that teachers " $[\ldots]$ used to talk more $[\ldots]$ get together and discuss [...] The technical course teachers cannot do this alone. So we have to do this together with the language teachers to try to help students to communicate, to read a catalogue, a book [...].According to data interpretation, the interdisciplinary work proposed by the institution, also called as team teaching or collaborative teaching (DUDLEY-EVANS; ST. JOHN, 1998; ROBINSON, 1991), is not happening at the institution. This collaborative teaching is, in the engineer's opinion, an important feature to oil and gas language teaching.Besides the interview, it is important to mention that the engineer worked with us to develop our proposal, explaining important characteristics of the profession and the industry and also providing authentic materials to be used in the classroom.

Both teachers interviewed considered to be highly important to develop activities to work with oral and written genres, since both would be part of the variety of genres present in the technician workplace situations. Therefore, we understood that we should consider some of these genres together to develop the design of teaching ESP at technical courses. Based on the analysis of the documents, the questionnaire and the interviews, we could design an ESP teaching proposal for oil and gas vocational courses as follows: 
Figure 1: ESP teaching proposal for oil and gas vocational courses. Source: Guerra $\left(2017\right.$, p. 95) ${ }^{1}$.

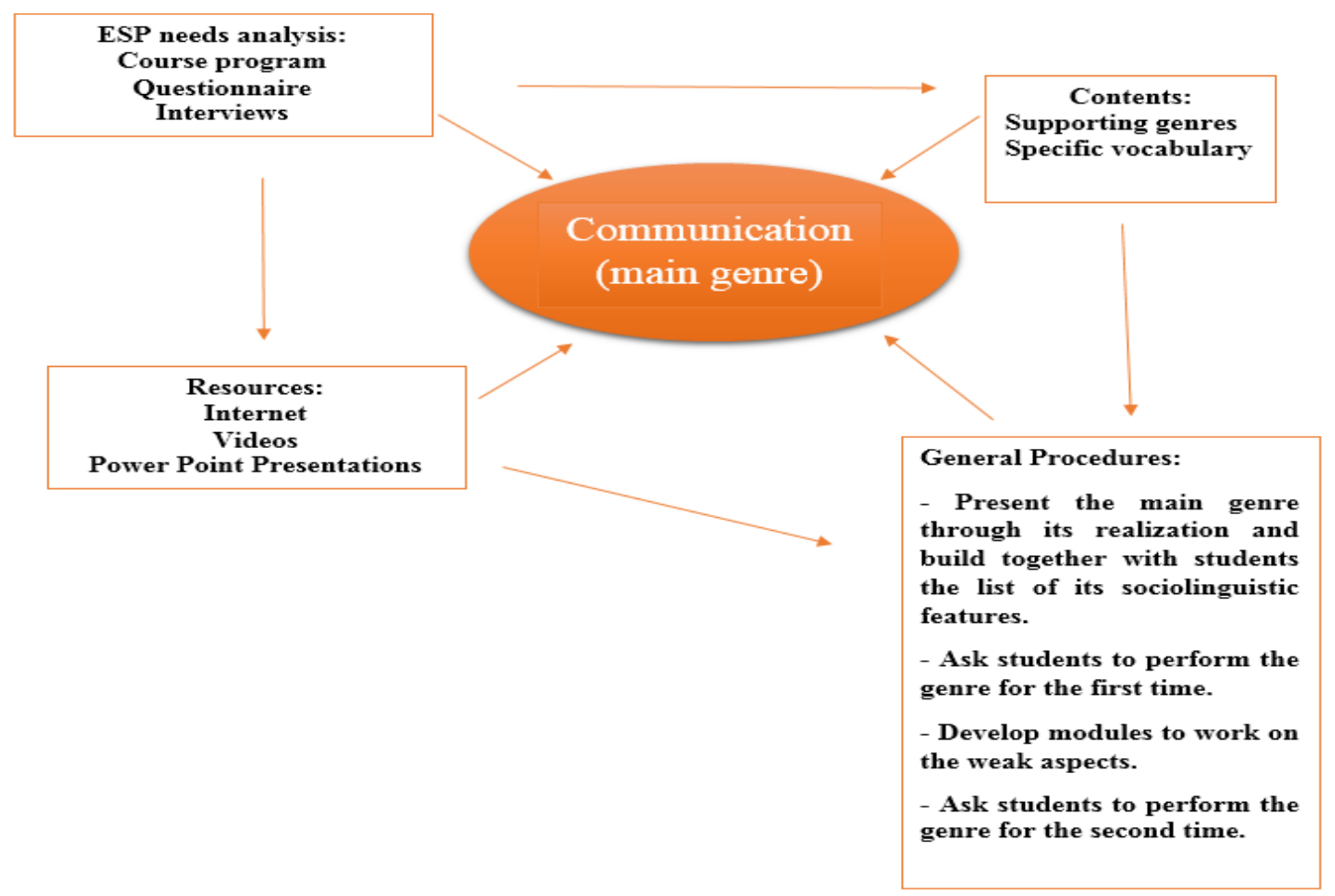

The design of the proposal is divided into 4 general sections, namely: ESP needs analysis, contents, resources and general procedures. Two main aspects were considered in order to design our proposal: reading and communication. Both students and teachers believe that it is extremely important to develop reading activities that consider the genres that the oil and gas technicians may deal with in their possible future working contexts. Reading is also the focus of the IFRN documents that guide the work of the teachers. The main difference is that the Course Pedagogical Program does not consider the genres mentioned by the students and the teachers (manuals, catalogues). Regarding the work with oral genres, categorized by the participants as communication,it is minimized by the document of the institution and highly mentioned by the students and the teachers, who highlighted informal dialogues, lectures and mainly business meetings as part of their (future) professions.

From ESP needs analysis the English teacher can make choices that reflect on the delimitation ofthe communication goal that represents the main genre, the resources that can be used in the classes and the content. This relation is represented by the arrows in Figure 1. ESP needs analysis can be carried out by questionnaires and interviews, as encouraged by ESP principles. A critical analysis on possible pre-determined course program is also needed, since an ESP program should be flexible and open to unpredicted information that can be given by the participants of the process, students and other teachers and professionals.

The basic resources illustrated are not only motivated by the result of the needs analysis but also by supporting a multimodal class and the potential of technology affordance to the teaching of a foreign language. Internet, videos and Power Point presentations represent only some of the technology teachers can use to look for materials and use the materials after editing in their classes. Creativity also plays an important role to make the choices in this section, as digital technology is not the reality of all educational settings in Brazil or other developing countries. As our proposal emerges around an oral genre as its communication goal, other supporting genres are predicted in the contents. The diversity of texts can be motivated either by ESP needs analysis or the principles of a multiliteracies pedagogy committed to educate students for professional and citizen performances through an integrated education. Specific vocabulary is seen as a certain result from the choice of multiple genres that are practiced in possible professional contexts.

In relation to general procedures, it is important that teachers find different realizations to make students familiar with the language and the social and professional context. Different examples of the same genre are necessary to make students aware of the flexibility and the constrains of the genre, characteristics that should be highlighted, listed and discussed together with students in order tomake sociolinguistic features more or less tangible.

\footnotetext{
${ }^{1}$ Free translation from Portuguese into English by the authors of this paper
} 
Students then should perform the genre for the first time after making conscious choices of the characteristics they use in their performance to the detriment of others. After giving feedback, the teacher is aware of the sociolinguistics aspects that need to be improved and can plan more carefullythe actions that eventually make students' first production better. The last general procedure is represented by students' performance of the genre for the second time so the progress can be assessed and there is information for a reflective teaching.

The proposal presented here isplanned to be accomplished in two months, during a 90-minute class once a week. We recommend the division of the lessons as follows: 1 lesson for the study of the genre and its characteristics; 1 lesson for the performance of the genre by the students for the first time; 6 classes for the development of sociolinguistic features to enhance students' performance; 1 lesson for the performance of the genre by the students for the second time (Cf.LIMA; GUERRA, 2018).Due to the short period of time dedicated to ESP in the context of our scope, some homework activities have to be proposed in order to make students engage in their tasks. The period of two months may be seenasshort, but this is meant to be a flexible guide to help teachers think about possible ways to teach ESP in technical courses.

\section{Future Directions}

In this paper, data analysis intended to elucidate how ESP is being consideredby a federal institution responsible for the offer of vocational education in Brazil.Through the analysis of documents that guide teaching, available on the website of the institution, and an ESP needs analysis, a designof ESP teaching in technical course emerged. Through the analysis of IFRN official documents, questionnaires and interviews, we were able to design an ESP proposal that can guide English teachers who work in technical education or at least make them think about possible ways to develop their work with ESP. We believe that the teaching of ESP should take into consideration the perspective of the pedagogy of multiliteracies and discourse genres by understanding that these theories may meet the specific principles of an ESP course. This way, teaching reading, writing, grammar and vocabulary, a highlighted characteristic found in our data, can be reframed in order to meet students' needs that might result in some information not predicted in predetermined course programs and syllabus.

The ESP proposal here is not a manual to be followedwithout a teacher critical perspective; it is a guide to make teachers aware of teaching with informed theory, meaningful choices and data collection and analysis. The proposal does not claim to be the best way to consider teaching ESP, but it intends to present a way that does not follow the pattern of ESP curriculums and pedagogical practices that are concerned only with reading specific vocabulary from a technical field.

Through our research, we believe we can start thinking about possibilities for the teaching of ESP in countries where the conscious of the importance of English is already a common sense, but the proficiency in the language is still quite low, like in Brazil. Action research to carry out the proposal is also needed and results should be publicized to continually induce critical changes in ESP curriculum design.

\section{References}

Brasil. LEI No 11.892, DE 29 DE DEZEMBRO DE 2008. Institui a Rede Federal de Educação Profissional, Científica e Tecnológica, cria os Institutos Federais de Educação, Ciência e Tecnologia, e dá outras providências. DIÁRIO OFICIALda República Federativa do Brasil,Brasília, DF, 30 dezembro de 2008. Seção II.

CELANI, M. A. A., HOLMES, J., RAMOS, R. DE C. G., \& SCOTT, M. (1988).The Brazilian ESP Project: an evaluation. São Paulo (SP): EDUC.

CELANI, M.A.A. (1998). A retrospective view of an ESP Teacher Education Programme. In: The ESPecialist, São Paulo, vol. 19 nº 2, p. 233-244. Available at: < http://revistas.pucsp.br/index.php/esp/article/view/9910>.

Cope, B; Kalantzis, M. (2009). "Multiliteracies": New literacies, New learning. In: Pedagogies. V. 4. n. 2. P. $196-204$.

Dudley-evans, A. \& St. John, A. M. (1998). Developments in ESP: A multidisciplinary approach. Cambridge: Cambridge University Press.

GUERRA, W. T. Ensino de inglês para fins específicos e multiletramentos na oferta técnica da escola pública. 2017. 139f. Dissertação (Mestrado em Ensino) - Programa de Pós-Graduação em Ensino (UERN, UFERSA, IFRN), Instituto Federal do Rio Grande do Norte, Mossoró, 2017.

Hutchinson, T.; Waters, A. (1987).English for Specific Purposes: A Learning Centred Approach. Cambridge: Cambridge University Press.

LIMA, S. C.; GUERRA, W. T. A aplicação de uma proposta de ensino de ESP no curso técnico de nível médio subsequente em $\mathrm{P} \& \mathrm{G}$ (no prelo). 
New London Group. (1996). A pedagogy of multiliteracies: Designing social futures. Harvard Educational Review, 66(1), 60. http://doi.org/Article

Portal do Instituto Federal de Educação, Ciência e Tecnologia do Rio Grande do Norte (IFRN). 2012. Available in < http://portal.ifrn.edu.br/>. Access in June, $29^{\text {th }}, 2017$.

Portal do Instituto Federal de Educação, Ciência e Tecnologia do Rio Grande do Norte (IFRN). 2012. Projeto Pedagógico do Curso Técnico Subsequente em Petróleo e Gás. Available in <http://portal.ifrn.edu.br/campus/mossoro/cursos/cursos-tecnicos-subsequentes/petroleo-e-gas.html>. Access: June, $29^{\text {th }}, 2017$.

Ramos, R. de C. G. (2008). ESP in Brazil: history, new trends and challenges. In: Krzanowski, M. (Ed.). ESP and EAP in Developing and in Least Developing Countries. IATEFL, 68-83.

Robinson, P. (1991). ESP today: a practitioner's guide. Hemel Hempstead: Prentice Hall. 146p. 